\title{
EFFECTS OF WATER OF REDUCED SALINITY ON THE VERTICAL MIGRATION OF ZOOPLANKTON
}

\author{
By Joan LANCE \\ Department of Zoology, University of Southampton ${ }^{1}$
}

(Figs. I-II)

Under estuarine conditions, the restriction of different species of zooplankton to certain ranges of salinity may be partly determined by behavioural patterns which tend to maintain each species in a suitable environment. The presence of a salinity discontinuity layer (i.e. a boundary between two types of water of varying salinity) is thought to restrict upward or downward movements of certain animals (Henschel, 1939; Hansen, I951; Carrriker, 1951; Mankowski, I95I) and in stratified estuaries it is probable that discontinuity layers will influence the dispersal of zooplankton by modifying the position of individuals relative to prevailing water currents. There is an obvious need to supplement existing field records by laboratory experiments, but although the reactions of small copepods have been investigated in the laboratory by several workers, it would appear that only Loeb (1893), Rose (1925), Lukjanova (1938) and Harder (1952 a, $b, 1954,1957 a, b)$ have conducted work on the behaviour of copepods in diluted sea water. The experiments described in this paper were designed to simulate the type of stratification likely to occur in estuaries such as Southampton Water where fresh water flows out over denser sea water, vertical mixing being incomplete. By recording the vertical distribution of planktonic crustaceans in stratified water and by observing the effects of specific dilutions on swimming activity, it was hoped that some indication of the way in which animals react to hydrographic events occurring in the field might be obtained.

\section{MATERIALS AND METHODS}

Plankton was collected from Southampton Water in the main channel parallel to the New Docks at Marchwood and in the vicinity of Hook Buoy at Calshot. While the salinity of sea water at the more seaward station Calshot varies between approximately 34 and $31 \%$, considerable reduction in salinity occurs at Marchwood where fresh water flows out from the River Test. Net hauls of Io min duration were always taken during the $2 \mathrm{~h}$ period which separates

\footnotetext{
1 Present address: Department of Zoology, University of Hull.
} 
the two pronounced high-water crests characteristic of Southampton Water, and under these conditions, it was assumed that animals were captured in water of high salinity. (Analyses of water samples taken from Marchwood townettings indicated salinity values of $31-33 \%$ ). Tow-nettings were transferred to breffits and taken to the laboratory within $\mathrm{I}-2 \mathrm{~h}$. As local sea water was frequently polluted, it was removed from tow-nettings and replaced by Plymouth outside sea water which had been filtered through Whatman no. I paper. Organisms were placed in a shaded part of an aquarium at a temperature similar to that prevailing in the field at the time of capture. Subdued natural illumination was used during sorting, and experiments were commenced $24 \mathrm{~h}$ after capture of the animals. Stage I and Stage II zoeae of the decapod Porcellana longicornis (Linneus) and adults of six copepod species, namely Acartia tonsa Dana, A. bifilosa (Giesbrecht), A. discaudata (Giesbrecht), A. clausi Giesbrecht, Centropages hamatus (Lilljeborg) and Temora longicornis (Müller), were selected for experiments. In addition, a few observations were made on adults of Centropages typicus Kröyer captured off Plymouth. The decapod larvae were given a diet of Phaeodactylum and pieces of Mytilus mantle while copepods were fed with a green flagellate Dunaliella cultured in Erdschreiber medium after the method of Gross (1937).

Under laboratory conditions, most of the planktonic organisms studied swam toward window light or artificial illumination. Experimental animals were therefore exposed to a constant overhead directional light stimulus and thus induced to swim upward in columns of water.

After sorting, zooplankton was stored overnight in a dark room at some distance from the experimental light source. On the following day, the animals were used for experiments conducted in the dark room at $20^{\circ} \mathrm{C}$. The main apparatus consisted of tall rectangular perspex vessels (with external dimensions $50 \mathrm{~cm} \times 4 \mathrm{~cm} \times 7.5 \mathrm{~cm}$ and with walls $0.5 \mathrm{~cm}$ thick) containing water. The number of animals placed in each water column ranged from 46 to 70 (depending on the abundance of various species in tow-nettings) and vertical distribution was recorded by observing the position of individuals along the length of the column. A $40 \mathrm{~W}$ electric light bulb arranged overhead $30 \mathrm{~cm}$ from the top of the vessel was used as a light source. A glass heat screen $(0.5 \mathrm{~cm}$ thick) was supported midway between the vessel and the light, and if several vessels were used, each column was shielded from neighbouring lights.

In all experiments, water of reduced salinity was prepared by diluting Plymouth sea water (which had a salinity of approximately $36 \%$ owing to evaporation during storage) with distilled water. Each dilution has been expressed as a percentage of full strength sea water (\% s.w.), Plymouth sea water being $100 \%$ s.w. 


\section{Vertical distribution in the presence of salinity discontinuity layers}

Columns of water were prepared so that animals had to pass through one or more salinity discontinuity layers in order to reach the upper levels of each column. The layers were produced by placing less dense diluted sea water over water of higher salinity. Homogeneous columns of full strength sea water were also set up so that the behaviour of animals in undiluted sea water could be recorded.

In the first series of experiments, the vertical distribution of animals in the presence of a single discontinuity layer positioned half-way up the water column was recorded, the experimental procedure being divided into several stages whereby the difference in salinity between the upper and lower halves of the column was progressively increased. The reaction of animals to light was first observed in full strength sea water. $450 \mathrm{ml}$. sea water containing a known number of organisms were poured into the experimental vessel to form the lower half of the water column. When currents had diminished, a further $450 \mathrm{ml}$. were added from a reservoir to give a column $45 \mathrm{~cm}$ high. The vertical distribution of animals was recorded Io min later and this will be referred to as the 'control response'. The upper half of the control column was then slowly removed using a siphon. The zooplankton was unable to escape through fine netting attached to the end of the siphon and therefore became concentrated in the lower half of the column. The full strength sea water thus removed was replaced by a corresponding volume of $90 \%$ s.w. flowing in slowly from a reservoir. The end of the inflow tube ( $8 \mathrm{~mm}$ internal diameter), covered with fine netting, was positioned so that it just touched the surface of the uncompleted column. The less dense diluted sea water gradually spread over the surface of the full strength sea water producing a distinct discontinuity layer and the end of the inflow tube was slowly raised to maintain contact with the rising surface. Mixing between the two types of water was negligible and the water column was completed within $15 \mathrm{~min}$. Io min later the vertical distribution of animals was again recorded. During the next stage in procedure, the $90 \%$ S.W. was slowly siphoned away with the end of the outflow tube held close to the surface. In this manner, all the diluted sea water and a small portion of the full strength sea water were removed and, as before, animals were retained in the vessel. The height of the column was readjusted to the half-way level by adding more full strength sea water and then $80 \%$ s.w. was added to the column by the method already described. The procedure was repeated for a range of salinities, the vertical distribution of animals being recorded each time. After results had been obtained for the last dilution in the range, the diluted sea water was replaced by full strength sea water so that a final control response in a homogeneous column could be recorded. Both initial and final control columns were completed in two halves in order to make the procedure comparable to that adopted for layering diluted sea water. 
Cotton threads tied around the outside of the vessel divided the water column into twelve sections, and the number of animals present in each section was counted. Since animals swimming close to the bottom of the vessel could not be seen clearly, distribution in the lowest section was recorded by subtracting the counts of all other sections from the total number of animals present. A half-way mark indicated the position of the discontinuity layer. Preliminary tests using diluted sea water stained with methylene blue had previously shown that mixing during layering was slight, the discontinuity being restricted to a narrow zone extending approximately $2 \mathrm{~mm}$ in height midway between the diluted sea water above and the full strength sea water below. Three small sections, each extending $2.5 \mathrm{~cm}$ in height, were marked off both above and below the half-way mark so that the distribution of animals close to the discontinuity layer could be recorded accurately. The remainder of the column was divided into sections which were $5 \mathrm{~cm}$ high. Tests showed that rapid successive counts of copepods gave similar results so a single count was taken after each column had been prepared. The larvae of Porcellana longicornis were more difficult to observe as they made rapid vertical excursions and results represent the mean of duplicate counts.

In the second series of experiments, the distribution of animals in the presence of a vertical series of discontinuity layers was recorded. The experimental column was divided into several sections, each extending $5 \mathrm{~cm}$ in height, and cotton threads marking the upper and lower limits of these sections also indicated the positions of the discontinuity layers. The section at the bottom of the vessel was filled with full strength sea water (approximately Ioo ml.) containing a known number of animals. Each section above was filled in turn with an appropriate dilution by means of a reservoir and inflow tube as already described so that a gradation was established from undiluted sea water at the bottom through several dilutions to water of the lowest salinity at the top. The salinity of each section differed from that of the neighbouring sections by either $10 \%$ s.w. or $5 \%$ s.w. The column was completed within $\mathrm{I} h$ and, after a further Io min, the number of animals present in each section was counted. At the same time, the distribution of a second group of animals was recorded in a control column which had been prepared in a similar manner except that full strength sea water was used in all sections. The height of the experimental column, which was identical to that of the control column, varied from 25 to $40 \mathrm{~cm}$ according to the range of dilutions used in the different experiments.

\section{Vertical distribution in water of different salinities}

The vertical distribution of animals in a range of homogeneous water columns, $45 \mathrm{~cm}$ high and of varying salinity, was recorded. Animals were transferred directly from full strength sea water to the different experimental salinities, each vessel being gently shaken to distribute the organisms through- 
out the column. After I 5 min, by which time all major currents had subsided, the number of animals present in the upper half of each column was recorded and counts were repeated at intervals during the main experimental period which lasted for $\mathrm{I} 2 \mathrm{~h}$ or less. In addition, a final count was usually made after I8 or $24 \mathrm{~h}$. The distributions of animals retained in control columns of undiluted sea water were observed both at the beginning and at the end of all experiments.

\section{RESULTS}

VERTICAL DISTRIBUTION IN THE PRESENCE OF A SINGLE DISCONTINUITY LAYER

\section{Behaviour in control columns}

When behaviour of the species from Southampton Water was observed in homogeneous control columns of full strength sea water, many individuals swam up toward the light source although a few gave photonegative reactions. Thus the number of animals migrating to the upper half of the initial control column ranged from $6 \mathrm{I}$ to $9 \mathrm{I} \%$ of the total number of specimens used and a similar range of $60-88 \%$ was recorded for the final control column. Centropages typicus differed from the Southampton species in that fewer individuals gave photopositive responses, only $44-46 \%$ being observed in the upper half. The number of each species counted in the upper half of the final control column was either identical to or lower than the initial control value. The overall changes in distribution were small and differences between initial and final responses varied from o to $4 \%$ representing a decline in numbers of only 0-2 animals. Hence any marked changes in distribution occurring in an experiment could be attributed to dilution effects alone.

\section{Behaviour in the presence of each discontinuity layer}

Results obtained from the different species show that discontinuity layers had a marked effect on vertical distribution. Thus for each species, the number of animals counted in the upper half of the control column was greater than the number observed above each discontinuity layer. Results are summarized in Table I where the numbers of animals counted in the upper half of the column under varying experimental conditions are expressed as percentages of the total number of animals used. As the salinity of the upper half was gradually lowered, there was a progressive decline in the number of individuals swimming through the discontinuity layer into the upper levels of the vessel. At the lowest salinities, very few specimens were observed in the upper levels and ultimately the difference in salinity between the two halves of the column became so great that no animals succeeded in swimming up through the discontinuity layer. With females of Acartia bifilosa, no copepods swam above the half-way mark when the salinity of diluted sea water in the column was reduced to $20 \%$ s.w. or below. For all other species, no further dilutions 
TABLE 1. DISTRIBUTION OF VARIOUS SPECIES WITH A SINGLE DISCONTINUITY LAYER

The numbers of animals recorded in the upper half of the water column are expressed as percentages of the total number of animals used. No. of $\%$ of animals present in upper half of column when the salinity ( $\%$ s.w.) of the upper half was varied

\begin{tabular}{|c|c|c|c|c|c|c|c|c|c|c|c|c|c|}
\hline \multirow{2}{*}{ Species } & \multirow{2}{*}{$\begin{array}{l}\text { animals } \\
\text { used }\end{array}$} & \multicolumn{2}{|l|}{ 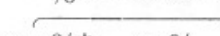 } & \multirow[b]{2}{*}{$80 \%$} & \multirow[b]{2}{*}{$70 \%$} & \multirow[b]{2}{*}{$60 \%$} & \multirow[b]{2}{*}{$50 \%$} & \multirow[b]{2}{*}{$40 \%$} & \multirow[b]{2}{*}{$30 \%$} & \multirow[b]{2}{*}{$20 \%$} & \multirow[b]{2}{*}{$10 \%$} & \multirow[b]{2}{*}{$5 \%$} & \\
\hline & & $100 \% \%^{\star}$ & $90 \%$ & & & & & & & & & & \multirow[t]{2}{*}{$100 \%$} \\
\hline & & & & & & & & & & & & & \\
\hline $\begin{array}{l}\text { Females } \\
\text { A. bifilosa }\end{array}$ & 58 & 62 & 59 & 40 & 29 & 24 & I9 & Io & 7 & 5 & 3 & $\circ$ & 60 \\
\hline $\begin{array}{l}\text { A. bifilosa } \\
\text { Females }\end{array}$ & 58 & 9I & 88 & 86 & $8 \mathrm{I}$ & 64 & 29 & 5 & 2 & o & o & o & 88 \\
\hline A. discaudata & & & & & & & & 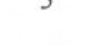 & & & & & \\
\hline Females & 57 & 72 & 68 & 63 & 58 & 19 & 9 & 4 & $\circ$ & - & - & - & 68 \\
\hline Males & 57 & $6 I$ & 58 & $5 \mathrm{I}$ & 40 & 16 & 7 & 4 & $\circ$ & - & - & - & $6 I$ \\
\hline A. clausi & & & & & & & & & & & & & \\
\hline $\begin{array}{l}\text { Females } \\
\text { Males }\end{array}$ & 54 & 78 & 70 & 69 & 50 & 26 & 9 & $\circ$ & - & - & - & - & 74 \\
\hline $\begin{array}{l}\text { Males } \\
\text { Centropages hamatus }\end{array}$ & 54 & 69 & 57 & 33 & 26 & I9 & 6 & 0 & - & - & - & - & 69 \\
\hline Females & 46 & 67 & 59 & 50 & 26 & I3 & o & - & - & - & - & - & 65 \\
\hline Males & 53 & $8 \mathrm{r}$ & 70 & $5 \mathrm{I}$ & 17 & 2 & o & - & - & - & - & - & 77 \\
\hline C. typicus & & & & & & & & & & & & & \\
\hline $\begin{array}{l}\text { Females } \\
\text { Males }\end{array}$ & 70 & 44 & 43 & 16 & 9 & 4 & $\circ$ & - & - & - & - & - & 44 \\
\hline $\begin{array}{l}\text { Males } \\
\text { Porcellana lonoicormis }\end{array}$ & 70 & 46 & 39 & 13 & 6 & 3 & 0 & - & - & - & - & - & 46 \\
\hline $\begin{array}{l}\text { Porcellana longicornis } \\
\text { Stage I zoeae }\end{array}$ & 62 & 84 & 62 & 48 & 32 & 24 & 15 & 0 & - & - & - & - & 82 \\
\hline Stage II zoeae & 62 & 78 & 62 & 49 & 32 & 22 & 12 & o & - & - & - & - & 77 \\
\hline
\end{tabular}

Percentages of animal distribution given in tables and graphs are calculated to the nearest whole figure. 
were employed after a salinity was reached at which the absence of animals above the discontinuity layer was first observed.

As the various species gave different control responses, it is necessary to analyse the data further before any quantitative differences in behaviour between species can be described. In Table 2, the number of animals entering the upper half of the stratified column is given for each species as a percentage of a standard control value. In each experiment, this control value is represented by the number of individuals counted in the upper half of the initial control column. For copepods (Fig. I), results suggest that the progressive fall in the number of animals present in the upper half of the stratified column may be represented by a sigmoid curve. The larvae of Porcellana longicornis (Fig. 2) showed a more regular fall in numbers with reduction of salinity and the graph approaches a straight line for both Stage I and Stage II zoeae.

The dilution used when no animals entered the upper half of the column will be referred to as the 'critical salinity'. It was found that Acartia tonsa had the lowest critical salinity ( $5 \%$ s.w.) followed by $A$. bifilosa $(20 \%$ s.w.), A. discaudata (30\% s.w.), A. clausi (40\% s.w.), Centropages hamatus (50\% s.w.) and C. typicus (50\% s.w.). Survival experiments on the Southampton species ${ }^{1}$ and on $C$. typicus (unpublished data) have established the following order of resistance to dilution for copepods: Acartia tonsa $>A$. bifilosa $>A$. discaudata $>A$. clausi $>$ Centropages hamatus $>$ C.typicus. Thus it would appear that the copepods which were most tolerant of dilution had the lowest critical salinities. The critical salinity recorded for the zoeae of Porcellana longicornis ( $40 \%$ s.w.) was identical to that given for Acartia clausi.

\section{Detailed changes in vertical distribution}

An accurate picture of the vertical distributions of different species was obtained by counting the number of animals present in the various sections of the experimental vessel. The results obtained for females of Acartia bifilosa are presented as a series of diagrams in Fig. 3. The distribution of copepods when the salinity of the upper half of the column was varied is indicated by a number of dots, each dot representing I copepod. The broken line, which divides the column in half, marks the position of the discontinuity layer. There was an active migration of copepods up toward the light in both initial and final control columns, but when $90 \%$ s.w. was used the pattern of distribution changed. Some of the copepods aggregated just above the discontinuity layer and fewer animals swam up toward the surface. With further lowering of salinity, the number of individuals migrating to the upper levels declined and copepods began to aggregate both above and below the discontinuity layer. Ultimately no copepods were counted in the upper half of the column and many animals aggregated just below the layer.

1 Lance, J., Ph.D. Thesis, University Southampton, I960. 
TABLE 2. DISTRIBUTION OF VARIOUS SPECIES WITH A SINGLE DISCONTINUITY LAYER

The numbers of animals recorded in the upper half are expressed as percentages of the number present in the upper half of the initial control column.

$C=$ No. of animals present in upper half of initial control column.

$\%$ of animals present in upper half of column when salinity (\% s.w.) of the upper half was varied

Species
Acartia tonsa
Females
A. bifilosa
Females
A. discaudata
Females
Males
A. clausi
Females
Males
Centropages hamatus
Females
Males
C. typicus
Females
Males
Porcellana longicornis
Stage I zoeae
Stage II zoeae

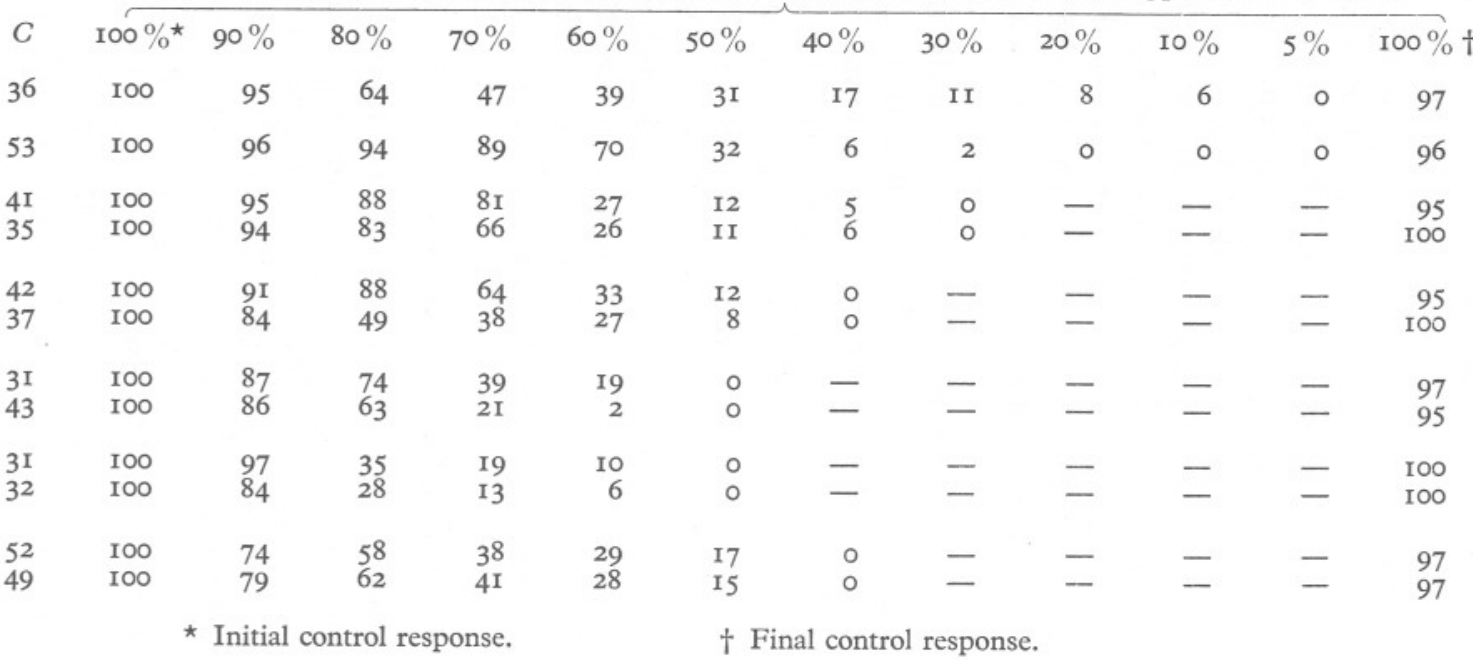



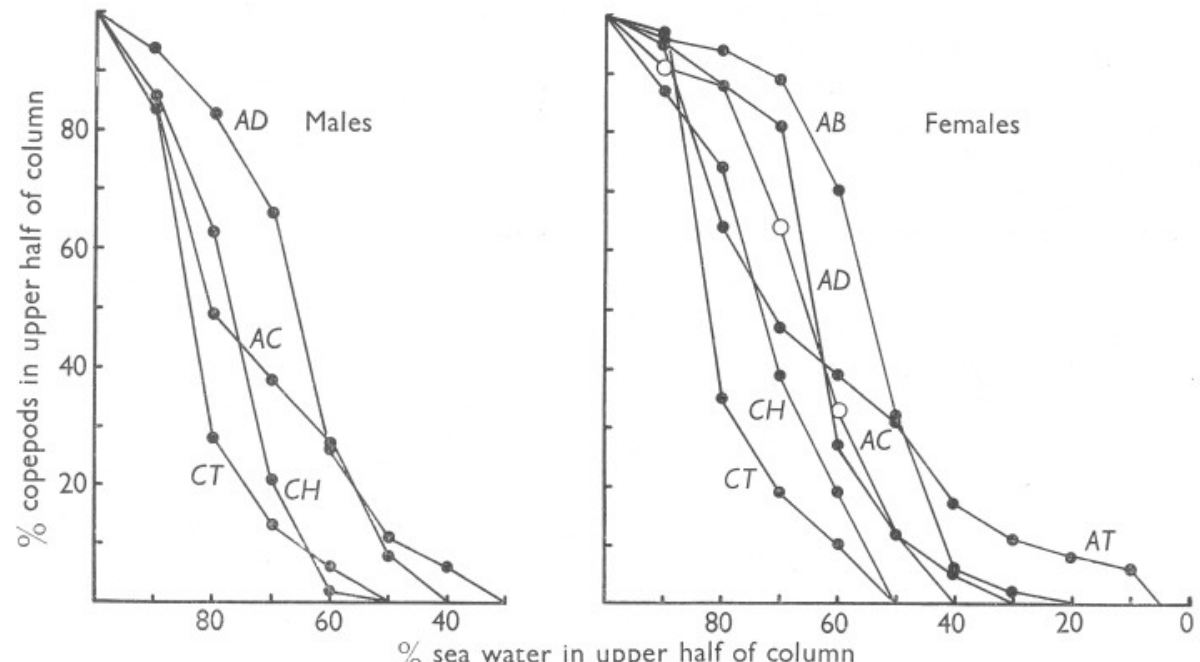

Fig. I. Vertical distribution of different copepod species in the presence of a single discontinuity layer. AB, Acartia bifilosa; $A C, A$. clausi; $A D, A$. discaudata; $A T, A$. tonsa; $\mathrm{CH}$, Centropages hamatus; CT, C. typicus.

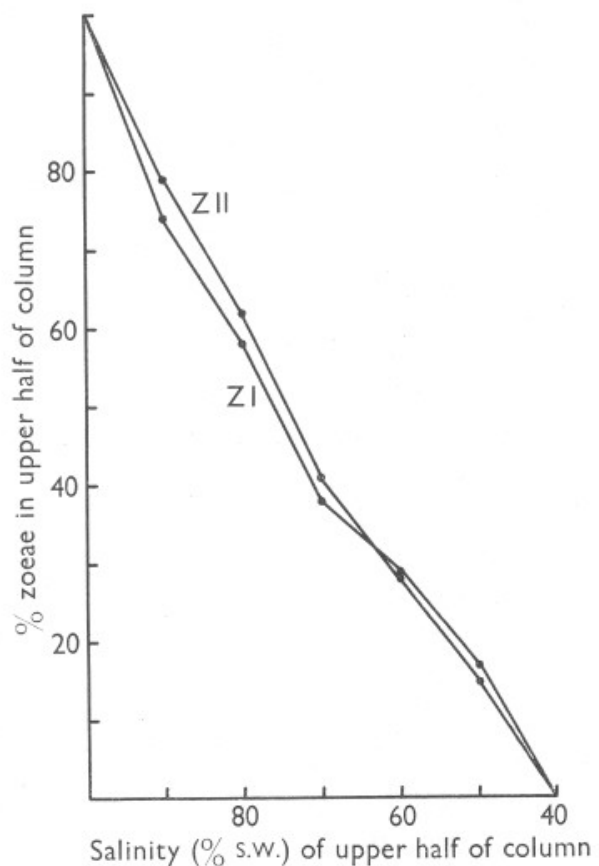

Fig. 2. Vertical distribution of Stage I zoeae (ZI) and Stage II zoeae (ZII) of Porcellana longicornis in the presence of a single discontinuity layer. 
Examples of the detailed changes in distribution occurring as the salinity of the upper half of the column was progressively lowered are given in Tables 3-6 which show the results obtained for female copepods and for zoeae. In each table the numbers of individuals counted in the different sections of the water column under varying conditions are expressed as percentages of the total number of animals used.
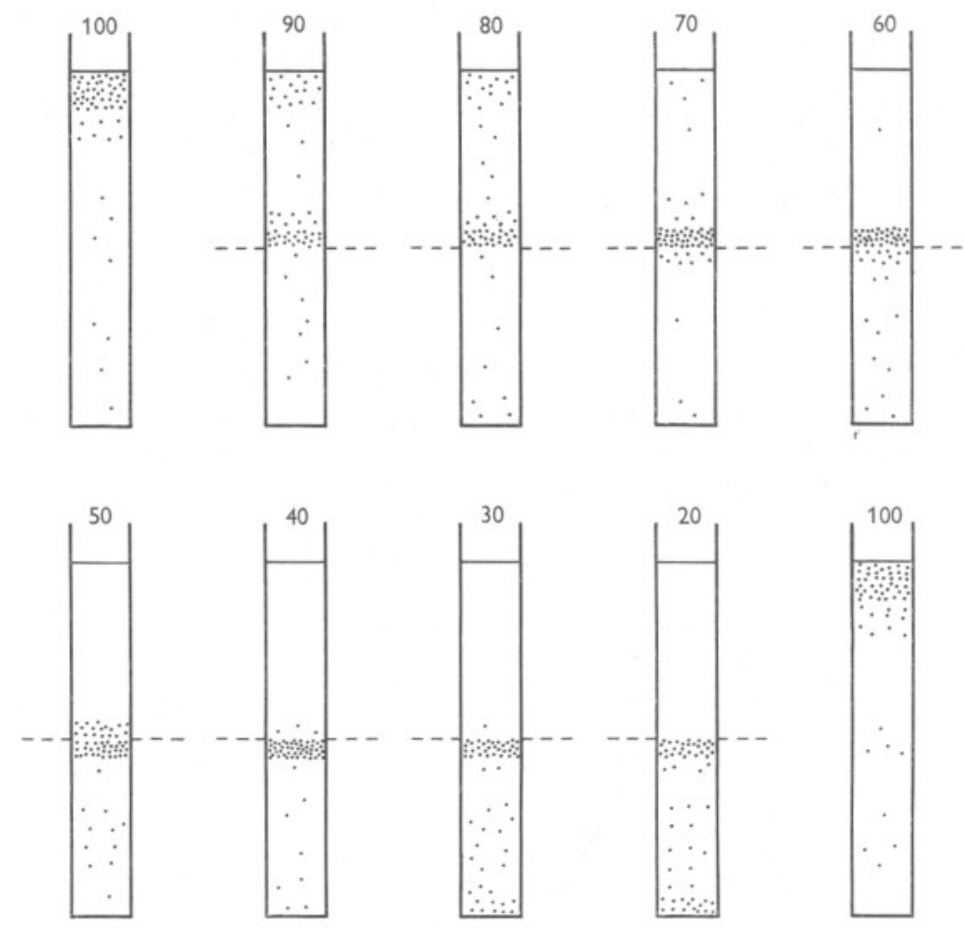

Fig. 3. Vertical distribution of Acartia bifilosa females in the presence of a single discontinuity layer. $100-20=$ salinity (\% s.w.) of upper half of column; each dot represents I copepod; $-\ldots$, position of discontinuity layer.

For the copepod species, males and females ceased to enter the top $5 \mathrm{~cm}$ of the column as soon as the salinity fell to $70 \%$ or $60 \%$ s.w. as against $50 \%$ s.w. for the zoeae of Porcellana longicornis. Vertical excursions became shorter and the numbers of individuals observed in the section immediately above the discontinuity layer rose to a maximum when either $80 \%$ S.W. or $70 \%$ s.w. was present. With further lowering of salinity, aggregation in this section tended to become less obvious and there was an interchange of animals swimming up and down through the discontinuity layer. Many of the animals migrating any distance into the zone of dilution subsequently sank motionless or with only feeble swimming movements into the saline water below. Here, 
TABLE 3. VERTICAL DISTRIBUTION OF ACARTIA TONSA AND ACARTIA BIFILOSA FEMALES IN THE PRESENCE OF A SINGLE DISCONTINUITY LAYER

\begin{tabular}{|c|c|c|c|c|c|c|c|c|c|c|c|c|c|c|c|c|c|c|c|c|c|c|}
\hline \multirow{3}{*}{$\begin{array}{l}\text { Height }(\mathrm{cm}) \\
\text { of each } \\
\text { section } \\
\text { of water } \\
\text { column }\end{array}$} & \multicolumn{22}{|c|}{$\%$ of copepods present in different sections when salinity ( $\%$ s.w.) of upper half of column was varied } \\
\hline & \multicolumn{12}{|c|}{ Acartia tonsa } & \multicolumn{10}{|c|}{ Acartia bifilosa } \\
\hline & $\overparen{100 \%}$ & $90 \%$ & $80 \%$ & $70 \%$ & $60 \%$ & $50 \%$ & $40 \%$ & $30 \%$ & $20 \%$ & $10 \%$ & $5 \%$ & $100 \%$ & $100 \%$ & $90 \%$ & $80 \%$ & $70 \%$ & $60 \%$ & $50 \%$ & $40 \%$ & $30 \%$ & $20 \%$ & $100 \%$ \\
\hline $\begin{array}{l}40-45 \\
35-40\end{array}$ & $\begin{array}{l}35 \\
\mathbf{2 2}\end{array}$ & $\begin{array}{r}28 \\
5\end{array}$ & $\begin{array}{r}12 \\
7\end{array}$ & $\begin{array}{l}5 \\
0\end{array}$ & $\circ$ & $\stackrel{\circ}{\circ}$ & $\stackrel{\circ}{\circ}$ & $\circ$ & $\circ$ & $\circ$ & $\stackrel{\circ}{\circ}$ & $\begin{array}{l}35 \\
21\end{array}$ & $\begin{array}{l}74 \\
12\end{array}$ & $\begin{array}{r}28 \\
3\end{array}$ & $\begin{array}{r}22 \\
3\end{array}$ & $\begin{array}{l}5 \\
2\end{array}$ & $\begin{array}{l}\circ \\
2\end{array}$ & $\stackrel{\circ}{\circ}$ & $\stackrel{\circ}{\circ}$ & $\stackrel{\circ}{\circ}$ & $\circ$ & $\begin{array}{l}69 \\
17\end{array}$ \\
\hline $30-35$ & 0 & 3 & 5 & o & o & o & o & 0 & 0 & 0 & 0 & $\begin{array}{r}21 \\
0\end{array}$ & 0 & $\begin{array}{l}3 \\
2\end{array}$ & 3 & 0 & 0 & 0 & 0 & 0 & 0 & $\begin{array}{r}17 \\
0\end{array}$ \\
\hline $27 \cdot 5-30$ & 2 & $\begin{array}{l}3 \\
5\end{array}$ & 5 & o & 7 & o & o & 0 & o & o & o & 3 & 2 & o & 2 & 5 & $\circ$ & 。 & o & o & o & o \\
\hline $25-27 \cdot 5$ & 3 & 9 & 3 & 5 & 9 & 0 & 0 & 0 & o & o & o & 2 & 2 & I4 & 12 & 3 & 0 & 0 & o & $\circ$ & o & 0 \\
\hline $22 \cdot 5-25$ & o & 9 & 7 & 19 & 16 & 19 & I0 & 7 & 5 & 3 & $\circ$ & 0 & 2 & $4 \mathrm{I}$ & 43 & 66 & 62 & 29 & 5 & 2 & 0 & 2 \\
\hline $20-22 \cdot 5$ & 0 & Io & I0 & 5 & 9 & I2 & 16 & $2 \mathrm{I}$ & I0 & I0 & 5 & o & 2 & 2 & 2 & I4 & I9 & 52 & $8 \mathrm{I}$ & 55 & 47 & 5 \\
\hline $15-17.5$ & o & o & 2 & 5 & 2 & 5 & 5 & 7 & I0 & 9 & 2 & 2 & 0 & 2 & 0 & o & 0 & o & 0 & 0 & o & 0 \\
\hline $10-15$ & 3 & o & 5 & 7 & 7 & 9 & 12 & 7 & I0 & 7 & 5 & 7 & 3 & 3 & 2 & 2 & 5 & 9 & 3 & Io & 9 & 2 \\
\hline $5-10$ & 2 & 0 & 5 & 5 & 5 & 7 & 12 & Io & 12 & 7 & 5 & 0 & 3 & 3 & 2 & o & 3 & 7 & 2 & 9 & 9 & 5 \\
\hline $0-5$ & 33 & $3 I$ & 35 & 43 & 43 & $4 \mathrm{I}$ & 43 & 43 & 47 & 52 & 72 & $3 \mathrm{I}$ & 0 & 0 & 7 & 3 & 5 & 2 & 7 & $2 \mathrm{I}$ & 29 & 0 \\
\hline
\end{tabular}

TABLE 4. VERTICAL DISTRIBUTION OF ACARTIA DISCAUDATA AND ACARTIA CLAUSI FEMALES IN THE PRESENCE OF A SINGLE DISCONTINUITY LAYER

\begin{tabular}{|c|c|c|c|c|c|c|c|c|c|c|c|c|c|c|c|c|c|}
\hline \multirow{3}{*}{$\begin{array}{l}\text { Height }(\mathrm{cm}) \\
\text { of each } \\
\text { section } \\
\text { of water } \\
\text { column }\end{array}$} & \multirow{2}{*}{\multicolumn{9}{|c|}{ Acartia discaudata }} & (\% s.v & ) of $u_{1}$ & er half & f colur & n was & ied & & \\
\hline & & & & & & & & & & \multicolumn{8}{|c|}{ Acartia clausi } \\
\hline & $100 \%$ & $90 \%$ & $80 \%$ & $70 \%$ & $60 \%$ & $50 \%$ & $40 \%$ & $30 \%$ & $100 \%$ & $100 \%$ & $90 \%$ & $80 \%$ & $70 \%$ & $60 \%$ & $50 \%$ & $40 \%$ & $100 \%$ \\
\hline $40-45$ & 60 & 54 & 40 & $\mathrm{I} 8$ & $\circ$ & $\circ$ & o & $\circ$ & 60 & 57 & 54 & 33 & 13 & 0 & $\circ$ & o & 54 \\
\hline $35-40$ & 7 & 4 & 7 & 7 & 2 & $\circ$ & & $\circ$ & 7 & 17 & $\begin{array}{l}6 \\
6\end{array}$ & 9 & 4 & $\circ$ & $\circ$ & ○ & 15 \\
\hline $30-35$ & $\begin{array}{l}0 \\
2\end{array}$ & $\begin{array}{l}2 \\
4\end{array}$ & $\begin{array}{l}5 \\
2\end{array}$ & ${ }^{7}$ & $\stackrel{\circ}{\circ}$ & $\begin{array}{l}\circ \\
0\end{array}$ & $\stackrel{\circ}{\circ}$ & & 0 & $\begin{array}{l}0 \\
0\end{array}$ & $\begin{array}{l}6 \\
0\end{array}$ & 9 & 4 & 0 & $\circ$ & $\begin{array}{l}\circ \\
0\end{array}$ & o \\
\hline $\begin{array}{l}27 \cdot 5-30 \\
25-27 \cdot 5\end{array}$ & $\begin{array}{l}2 \\
2\end{array}$ & $\begin{array}{l}4 \\
0\end{array}$ & 0 & $\begin{array}{l}0 \\
2\end{array}$ & $\begin{array}{l}0 \\
2\end{array}$ & $\begin{array}{l}0 \\
0\end{array}$ & $\begin{array}{l}\circ \\
\circ\end{array}$ & $\begin{array}{l}\circ \\
\circ\end{array}$ & $\begin{array}{l}0 \\
0\end{array}$ & $\begin{array}{l}0 \\
2\end{array}$ & $\begin{array}{l}0 \\
4\end{array}$ & $\begin{array}{l}4 \\
2\end{array}$ & 2 & 0 & 0 & 0 & $\begin{array}{l}0 \\
2\end{array}$ \\
\hline $22.5-25$ & 2 & 5 & 9 & 25 & $1 \overline{6}$ & 9 & 4 & 0 & 2 & 2 & 2 & II & 28 & 26 & 9 & 0 & 4 \\
\hline $20-22 \cdot 5$ & 2 & 0 & 0 & 7 & I4 & 19 & 23 & $2 \mathrm{I}$ & 2 & ० & o & 7 & 7 & 7 & II & 15 & o \\
\hline $17.5-20$ & 0 & 4 & o & o & 9 & 5 & 5 & 14 & 2 & o & 0 & 2 & 2 & 2 & 7 & 15 & $\circ$ \\
\hline $15-17.5$ & o & o & 2 & 4 & 4 & 4 & 7 & 9 & 0 & 0 & o & o & 4 & 4 & 9 & II & 0 \\
\hline $10-15$ & o & o & o & 2 & 9 & 5 & 7 & 4 & o & 4 & 6 & 4 & 4 & 6 & 7 & 4 & 2 \\
\hline $5-10$ & 0 & 0 & 0 & 0 & 7 & 12 & 9 & 4 & 0 & 0 & 7 & 2 & 2 & 6 & 7 & 4 & 7 \\
\hline $0-5$ & 26 & 28 & 35 & 30 & 39 & 46 & 46 & 49 & 28 & 19 & 17 & I7 & 31 & 50 & 48 & 52 & 17 \\
\hline
\end{tabular}


TABLE 5. VERTICAL DISTRIBUTION OF CENTROPAGES HAMATUS AND CENTROPAGES TYPICUS FEMALES IN THE PRESENCE OF A SINGLE DISCONTINUITY LAYER,

\begin{tabular}{|c|c|c|c|c|c|c|c|c|c|c|c|c|c|c|}
\hline \multirow{3}{*}{$\begin{array}{l}\text { Height }(\mathrm{cm}) \\
\text { of each } \\
\text { section } \\
\text { of water } \\
\text { column }\end{array}$} & \multicolumn{14}{|c|}{$\%$ of copepods present in different sections when salinity (\% s.w.) of upper half of column was varied } \\
\hline & \multicolumn{7}{|c|}{ Centropages hamatus } & \multicolumn{7}{|c|}{ Centropages typicus } \\
\hline & $100 \%$ & $90 \%$ & $80 \%$ & $70 \%$ & $60 \%$ & $50 \%$ & $100 \%$ & $100 \%$ & $90 \%$ & $80 \%$ & $70 \%$ & $60 \%$ & $50 \%$ & $100 \%$ \\
\hline $\begin{array}{l}40-45 \\
35-40\end{array}$ & $\begin{array}{r}59 \\
4\end{array}$ & $\begin{array}{r}39 \\
4\end{array}$ & $\begin{array}{r}26 \\
2\end{array}$ & $\begin{array}{r}13 \\
2\end{array}$ & $\begin{array}{l}\circ \\
4\end{array}$ & $\begin{array}{l}\circ \\
0\end{array}$ & $\begin{array}{r}57 \\
2\end{array}$ & $\begin{array}{r}34 \\
4\end{array}$ & $\begin{array}{l}19 \\
13\end{array}$ & $\begin{array}{l}\text { I } \\
\text { I }\end{array}$ & $\begin{array}{l}\circ \\
0\end{array}$ & $\begin{array}{l}0 \\
0\end{array}$ & ○ & $\begin{array}{r}34 \\
\text { I }\end{array}$ \\
\hline $30-35$ & $\begin{array}{l}4 \\
0\end{array}$ & $\begin{array}{l}4 \\
2\end{array}$ & $\begin{array}{l}2 \\
2\end{array}$ & $\begin{array}{l}2 \\
0\end{array}$ & $\begin{array}{l}4 \\
2\end{array}$ & $\begin{array}{l}0 \\
0\end{array}$ & $\begin{array}{l}2 \\
2\end{array}$ & $\begin{array}{l}4 \\
0\end{array}$ & $\begin{array}{r}13 \\
1\end{array}$ & $\begin{array}{l}1 \\
4\end{array}$ & $\begin{array}{l}\circ \\
\circ\end{array}$ & $\begin{array}{l}\circ \\
\circ\end{array}$ & $\begin{array}{l}0 \\
0\end{array}$ & $\begin{array}{l}\mathrm{I} \\
4\end{array}$ \\
\hline $27 \cdot 5-30$ & 0 & 2 & 0 & 2 & 2 & 0 & 2 & 3 & 3 & I & o & 0 & 0 & 4 \\
\hline $25-27 \cdot 5$ & 2 & 0 & 7 & 2 & o & $\circ$ & 2 & o & 3 & o & 3 & 0 & $\circ$ & o \\
\hline $22 \cdot 5-25$ & 2 & II & 13 & 7 & 4 & 0 & $\circ$ & 3 & 4 & 7 & 6 & 4 & 0 & 0 \\
\hline $20-22 \cdot 5$ & o & 0 & 4 & I7 & 13 & 26 & 2 & o & 4 & 7 & 19 & 23 & 26 & o \\
\hline $17 \cdot 5-20$ & 0 & 2 & 2 & 2 & 17 & II & 2 & 4 & 3 & 4 & 6 & II & 10 & o \\
\hline $15-17.5$ & 2 & 2 & 4 & 9 & II & 7 & $\circ$ & I & I & 6 & 7 & 4 & 4 & I \\
\hline $10-15$ & 7 & 7 & II & 13 & II & 13 & 4 & 0 & $\circ$ & 4 & 4 & 6 & 3 & 3 \\
\hline $5-10$ & 7 & 4 & 9 & II & II & 15 & 9 & 3 & I & 9 & 4 & I & I & 4 \\
\hline $0-5$ & 17 & 26 & 20 & 22 & 24 & 28 & 17 & 47 & 47 & 54 & 51 & 50 & 56 & 47 \\
\hline
\end{tabular}

TABLE 6. VERTICAL DISTRIBUTION OF PORCELLANA LONGICORNIS ZOEAE IN THE PRESENCE OF A SINGLE DISCONTINUITY LAYER

\begin{tabular}{|c|c|c|c|c|c|c|c|c|c|c|c|c|c|c|c|c|}
\hline \multirow{3}{*}{$\begin{array}{l}\text { Height }(\mathrm{cm}) \\
\text { of each } \\
\text { section } \\
\text { of water } \\
\text { column }\end{array}$} & \multicolumn{14}{|c|}{$\%$ of zoeae present in different sections when salinity ( $\%$ s.w.) of upper half of column was varied } & & \\
\hline & \multicolumn{8}{|c|}{ Stage I zoeae } & \multicolumn{8}{|c|}{ Stage II zoeae } \\
\hline & $100 \%$ & $90 \%$ & $80 \%$ & $70 \%$ & $60 \%$ & $50 \%$ & $40 \%$ & $100 \%$ & $100 \%$ & $90 \%$ & $80 \%$ & $70 \%$ & $60 \%$ & $50 \%$ & $40 \%$ & $100 \%$ \\
\hline $\begin{array}{l}40-45 \\
35-40\end{array}$ & 65 & $\begin{array}{r}17 \\
8\end{array}$ & 2 & 2 & $\begin{array}{l}4 \\
3\end{array}$ & O & $\circ$ & 65 & $\begin{array}{l}59 \\
\mathrm{I} 2\end{array}$ & $\begin{array}{r}20 \\
7\end{array}$ & $\begin{array}{r}8 \\
\text { IO }\end{array}$ & 4 & $\begin{array}{l}3 \\
2\end{array}$ & O & $\circ$ & 57 \\
\hline $\begin{array}{l}35-40 \\
30-35\end{array}$ & $\begin{array}{r}15 \\
0\end{array}$ & 7 & $\begin{array}{l}7 \\
6\end{array}$ & $\begin{array}{l}7 \\
5\end{array}$ & $\begin{array}{l}3 \\
2\end{array}$ & $\begin{array}{l}1 \\
2\end{array}$ & o & 13 & $\begin{array}{r}12 \\
0\end{array}$ & $\begin{array}{l}7 \\
7\end{array}$ & 9 & $\begin{array}{l}3 \\
2\end{array}$ & $\begin{array}{l}2 \\
1\end{array}$ & $\begin{array}{l}1 \\
\text { I }\end{array}$ & 0 & $\begin{array}{r}17 \\
0\end{array}$ \\
\hline $27 \cdot 5-30$ & o & 5 & 4 & 2 & 3 & 2 & 0 & 2 & o & I & 6 & 2 & 3 & I & 0 & I \\
\hline $25-27 \cdot 5$ & 2 & II & 14 & 3 & 5 & 4 & o & I & 4 & 15 & 7 & 3 & 2 & 2 & 0 & I \\
\hline $22 \cdot 5-25$ & 2 & 15 & 16 & I4 & 7 & 7 & 0 & 2 & 3 & 14 & II & 17 & II & 8 & 0 & I \\
\hline $20-22.5$ & ○ & 7 & 17 & 22 & 28 & 36 & 37 & ○ & 2 & 6 & 15 & 26 & 32 & 32 & 42 & o \\
\hline $17.5-20$ & I & 2 & II & 7 & 7 & 13 & $\begin{array}{l}37 \\
16\end{array}$ & o & I & 3 & 3 & 9 & 9 & 16 & I0 & 2 \\
\hline $15-17.5$ & 0 & 2 & 0 & 7 & 8 & 7 & 8 & I & 2 & 2 & 2 & 7 & 7 & I0 & 10 & I \\
\hline $10-15$ & 0 & 5 & 3 & 7 & 8 & 7 & II & 2 & 3 & 3 & 8 & 7 & 8 & 6 & II & 3 \\
\hline $5-10$ & 0 & 4 & 2 & 7 & 7 & 3 & 5 & 0 & 0 & 3 & 6 & o & 6 & 4 & 4 & 4 \\
\hline $0-5$ & 15 & $\begin{array}{r}4 \\
19\end{array}$ & 19 & 19 & 17 & $\begin{array}{r}3 \\
19\end{array}$ & 23 & 15 & 14 & 21 & 18 & 19 & 17 & 20 & 23 & 14 \\
\hline
\end{tabular}


most individuals recovered and again attempted to swim up toward the light source. Eventually the difference in salinity between the two halves of the column became so great that many animals entering the upper half made violent swimming movements which carried them down into the saline water again. In the presence of the critical salinity, animals contacting the discontinuity layer recoiled so quickly that no individuals were recorded in the upper half of the column. The zoeae of $P$. longicornis were larger than the copepods and showed stronger swimming movements, continually flinging themselves toward the light. Such vigorous behaviour tended to carry the larvae some distance through a discontinuity layer before they recoiled. Even so the zoeae, which have been found to be less resistant to reduced salinity than Acartia tonsa, A. bifilosa and A. discaudata ${ }^{1}$ had a high critical salinity in common with those copepod species which were less tolerant of dilution. In all experiments, aggregation of animals in the section directly below the discontinuity layer was most obvious either during the intermediate stages of layering or when the critical salinity was present. There was a tendency for the number of animals observed in the bottom $5 \mathrm{~cm}$ of the column to increase when the column was stratified and for each species, numbers rose to a maximum when the critical salinity was used.

\section{Comparison of the behaviour of different sexes and larval stages}

Although control responses varied, direct comparisons of the behaviour of different sexes or larval stages of a species can be made since the results given in Table 2 are expressed relative to a standard control value. From the data obtained for Acartia discaudata, A. clausi, Centropages hamatus and C. typicus it is clear that the same critical salinity was recorded for both sexes of a species. However the males, which have been found to be less tolerant of dilution than the females, showed more marked changes in vertical distribution in the presence of certain discontinuity layers. Thus for each species, fewer males than females tended to swim up into the zone of dilution. On the other hand, Stage I and Stage II zoeae of Porcellana longicornis, which have been found to have identical salinity tolerances, ${ }^{1}$ showed no significant differences in behaviour.

\section{VERTICAL DISTRIBUTION IN THE PRESENCE OF A VERTICAL SERIES OF DISCONTINUITY LAYERS}

In each homogeneous control column of full strength sea water, most individuals migrated toward the light source and aggregated in the upper levels of the vessel. When the experimental column was prepared by placing several dilutions on top of each other, it was found for each species that animals were able to swim some distance up through the vertical salinity gradient. The total number of discontinuity layers present (4-7) varied with

\footnotetext{
${ }^{1}$ See footnote, p. 137.
} 
the different species, the experimental column being completed by adding a dilution which no animals would enter. Results are presented as a series of diagrams in Figs. 4-6. The width of each diagram represents the number of animals present in each indicated section of the control or experimental column, all numbers being expressed as percentages of the total number used in the column.
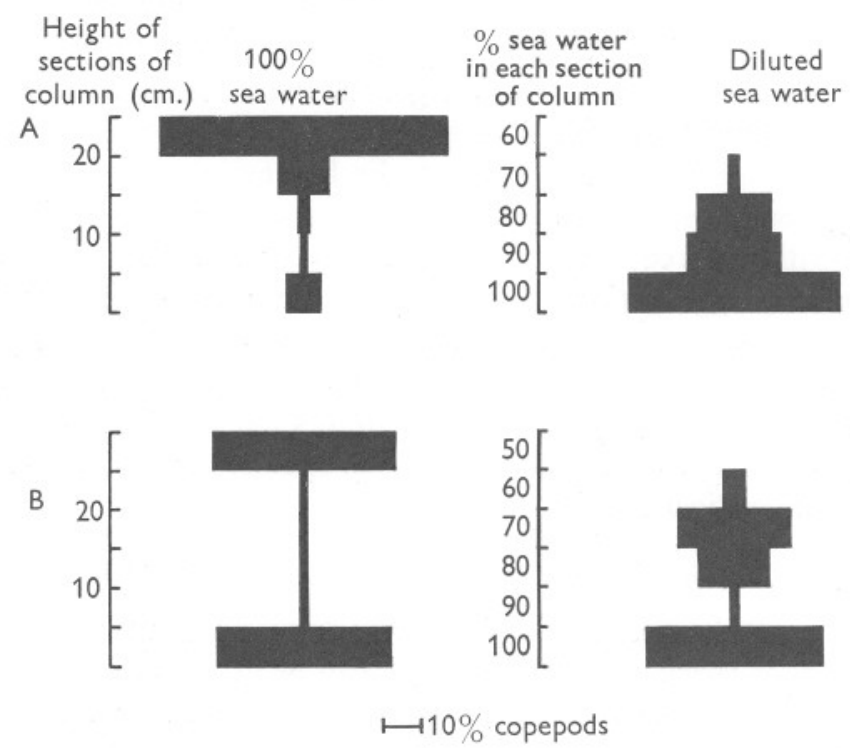

Fig. 4. Vertical distribution of copepods in the presence of a series of discontinuity layers. A, Acartia bifilosa (68 females used in each column); B, Temora longicornis ( 49 females used in each column).

When salinity differences of 10\% s.w. existed between neighbouring sections, many individuals of both Acartia bifilosa (Fig. 4A) and Centropages hamatus (Fig. $5 \mathrm{~A}$ ) collected in the full strength sea water at the bottom of the experimental column and the number of copepods migrating to the upper levels fell progressively as greater dilutions were encountered. Females of both species did not penetrate beyond $70 \%$ S.W. as against $80 \%$ S.W. for male Centropages hamatus. In contrast to these results, both Temora longicornis (Fig. 4B) and Porcellana longicornis (Fig. 6A) displayed strong swarming reactions and tended to aggregate in the intermediate sections; they also swam greater distances toward the light source so that a few individuals were observed in the section containing $60 \%$ s.w.

In the presence of discontinuity layers formed by salinity differences of $5 \%$ s.w., both sexes of Centropages hamatus (Fig. 5B) swam up as far as the $75 \%$ s.w. zone while a few Stage I and Stage II zoeae of Porcellana longicornis (Fig. 6B) entered the section containing $70 \%$ s.w. 


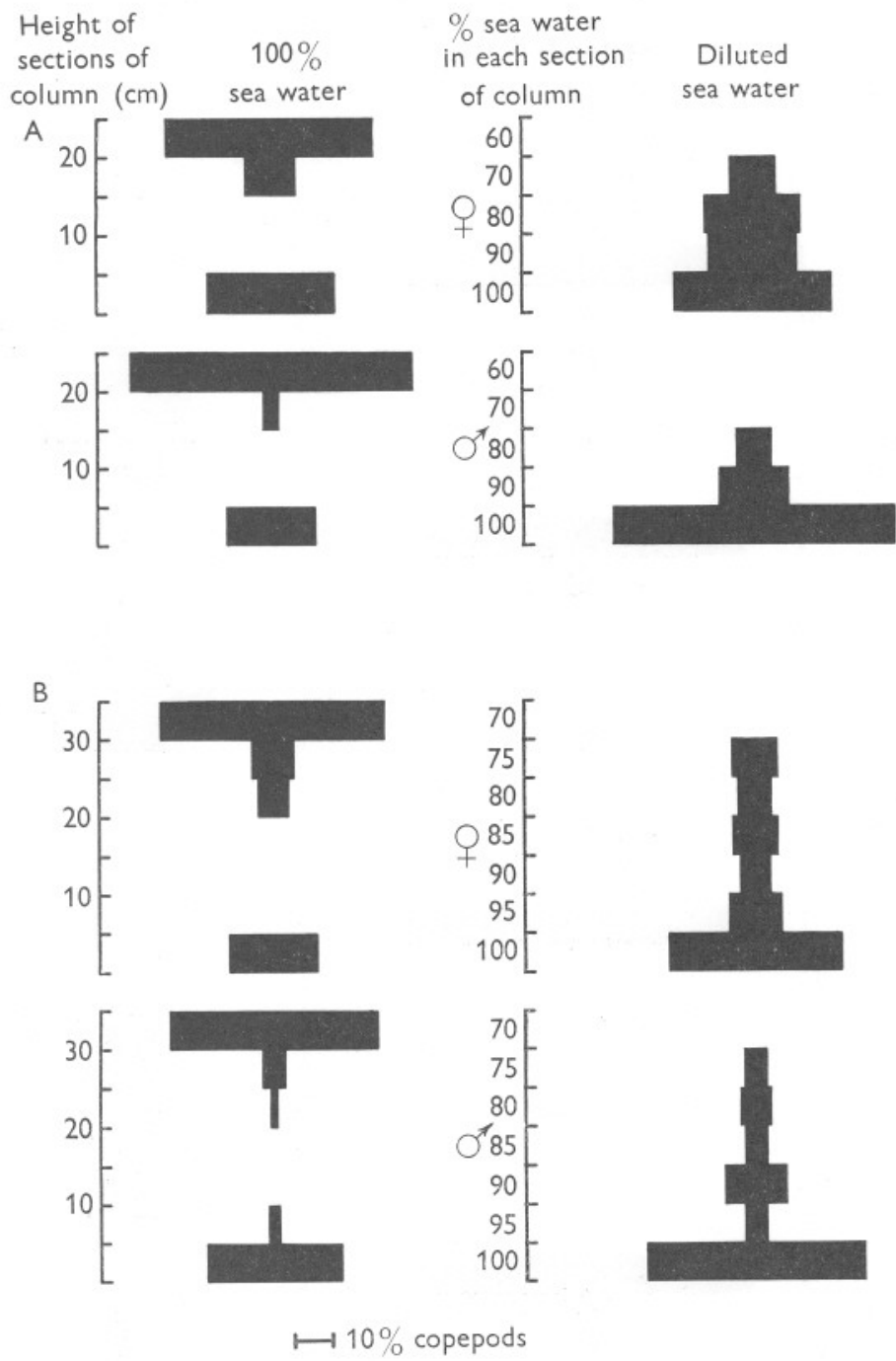

Fig. 5. Vertical distribution of Centropages hamatus in the presence of a series of discontinuity layers. A, Salinity differences of $10 \%$ S.w. ( 69 females or 56 males used in each column); B, salinity differences of $5 \%$ s.w. ( 65 females or 63 males used in each column).

\section{VERTICAL DISTRIBUTION IN WATER OF DIFFERENT SALINITIES}

The distribution of copepods in undiluted sea water was recorded by counting the number of animals swimming in the upper half of a control column of full strength sea water. Changes in the vertical distribution of copepods placed in experimental columns of diluted sea water were indicated by counting 
the number of animals present in the upper half of each column at different times and expressing the counts as percentages of the control number, allowances being made for any deaths occurring during each experiment.
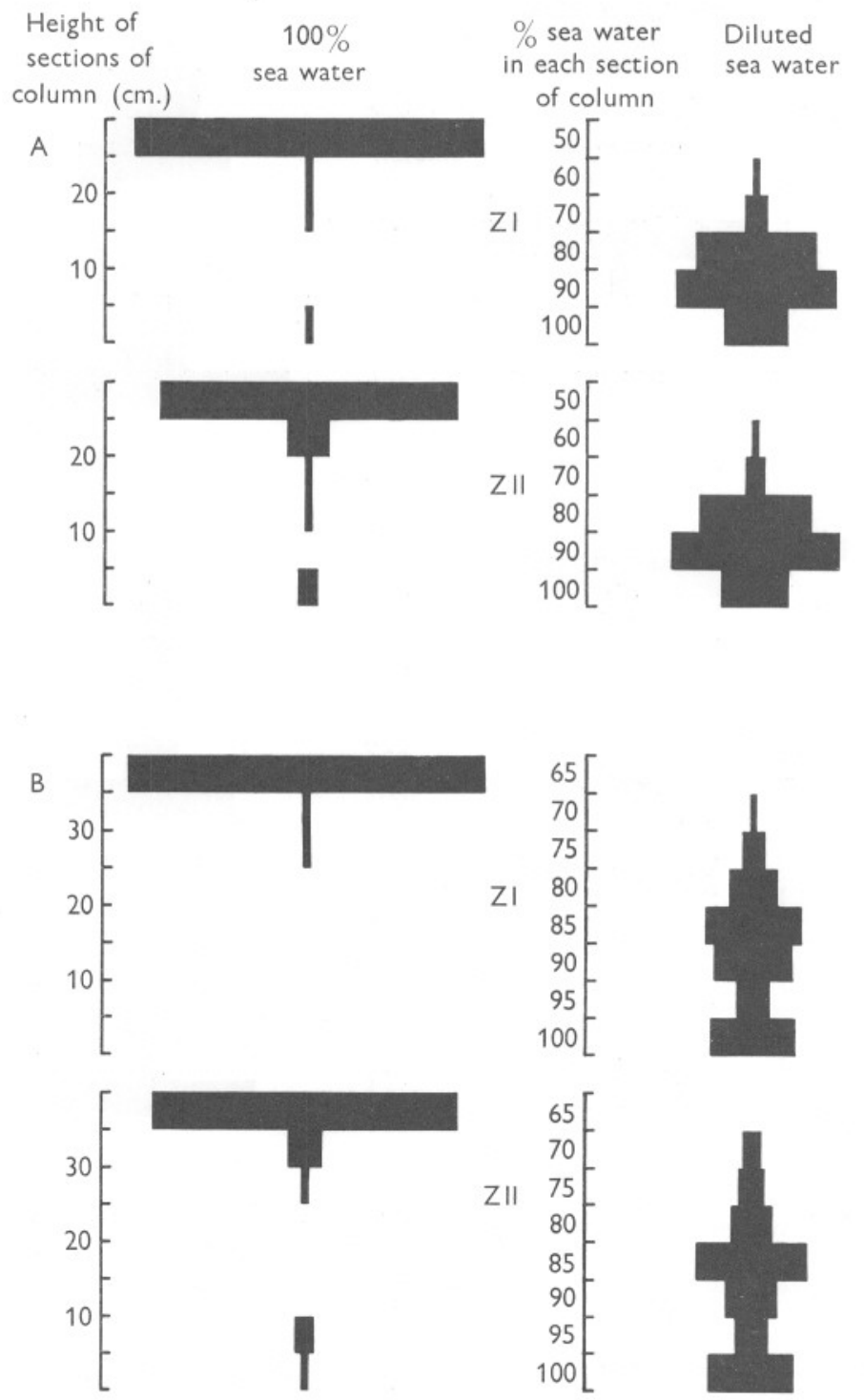

$$
\longmapsto 10 \% \text { zoeae }
$$

Fig. 6. Vertical distribution of Stage I zoeae (ZI) and Stage II zoeae (ZII) of Porcellana longicornis in the presence of a series of discontinuity layers. A, Salinity differences of 10 \% S.W.; B, salinity differences of $5 \%$ s.w. (47 Stage I zoeae or 56 Stage II zoeae used in each column). 
A preliminary study was made on Acartia clausi in two homogeneous columns of diluted sea water whereas the behaviour of Acartia tonsa, A. bifilosa and Centropages hamatus was investigated in greater detail using a wide range of reduced salinities. Adult females were used and the results for each species were obtained from one experiment only.

Data obtained for Acartia clausi and for Centropages hamatus from a single control column indicated that the distribution of copepods in undiluted sea water was unchanged during an experimental period of $6 \frac{1}{2}$ and $\mathrm{I} 2 \mathrm{~h}$ respectively. For both Acartia tons $a$ and A. bifilosa, no significant distribution changes were observed in three control columns over a period of $\mathrm{I} 8 \mathrm{~h}$ and $24 \mathrm{~h}$ respectively. Although for Centropages hamatus distribution remained unaltered during the main experimental $\mathrm{I} 2 \mathrm{~h}$ period, after $24 \mathrm{~h}$ fewer copepods were migrating toward the light and it was necessary to use only the final control count when analysing the final distribution of this species.

Figs. 7-10 show the results obtained for the various species. It was obvious from the behaviour of copepods soon after they were placed in water columns of reduced salinity that all dilutions modified vertical distribution. In all experiments distribution partly depended on the degree of dilution of the sea water, higher percentages of copepods being present in the upper levels of columns of higher salinity. Distribution also depended on the period of exposure since the numbers of copepods swimming in the upper half of most diluted columns progressively increased during the course of each experiment. After exposure to salinities ranging from $90 \%$ to $50 \%$ S.w. for $24 \mathrm{~h}$, the behaviour of Centropages hamatus (Fig. Io) did not differ markedly from that of copepods retained in full strength sea water while Acartia bifilosa (Fig. 9) showed identical distributions in both diluted and undiluted columns. In water of lower salinity, however, the distribution of these species after $24 \mathrm{~h}$ differed considerably from that of copepods in full strength sea water.

The data obtained for the different species are compared in Fig. II which shows the effects of dilution on distribution at varying time intervals during the main experimental period. Copepods placed in $90 \%$ and $80 \%$ s.w. initially showed irregular swimming and sinking movements. However, they soon recovered from this sudden change of environment and their distribution then showed only small differences from that of control animals in full strength sea water. In salinities lower than $80 \%$ s.w., violent swimming movements occurred and many copepods subsequently sank toward the bottom of the experimental vessel where they rested motionless apart from spasmodic twitching of the appendages. Thus in both $70 \%$ and $60 \%$ s.w., all copepods except for a few Acartia tonsa were confined to the lower levels of the column when observations were first made after $15 \mathrm{~min}$. The complete absence of $A$. tonsa from the upper half of the column did not occur until salinities lower than $60 \%$ s.w. were used. Except in extreme dilutions, individuals of each species tended to recover with time and swim up toward 


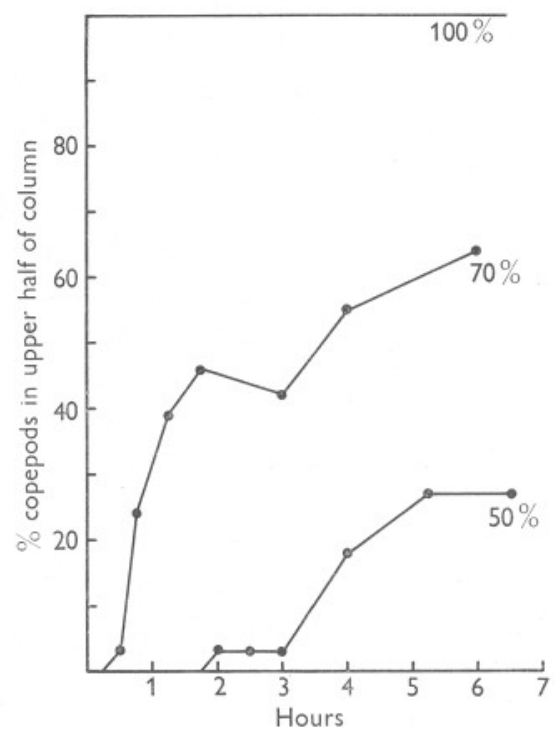

Fig. 7. Vertical distribution of Acartia clausi in water columns of different salinities ( 50 females used in each column). $100 \%-50 \%=$ salinity (\% s.w.).

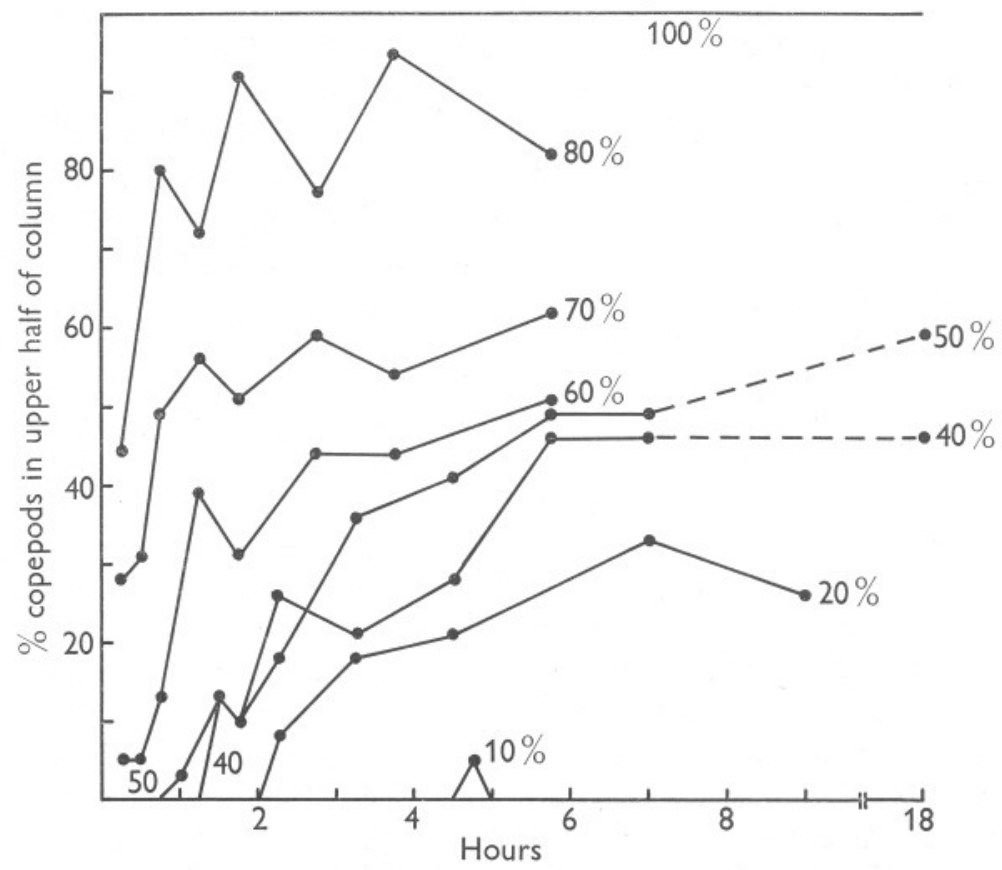

Fig. 8. Vertical distribution of Acartia tonsa in water columns of different salinities ( 60 females used in each column). $100 \%-10 \%=$ salinity (\% s.w.). 


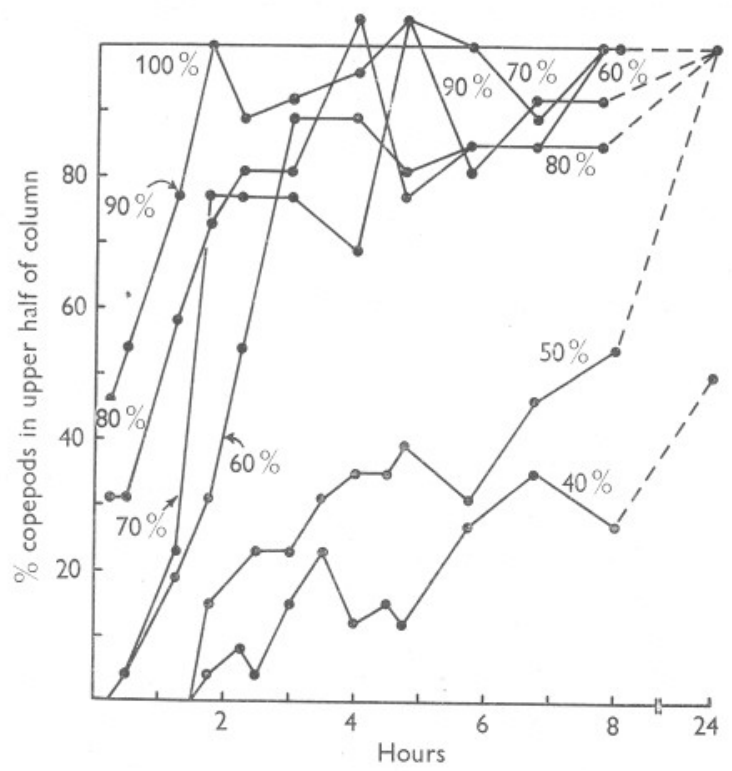

Fig. 9. Vertical distribution of Acartia bifilosa in water columns of different salinities (50 females used in each column). $100 \%-40 \%=$ salinity ( $\%$ s.w.). The control number used for calculations is a mean value obtained from the results of 3 control columns; the percentages over 100\% obtained for some readings fall within the small range of variation recorded for these control columns.

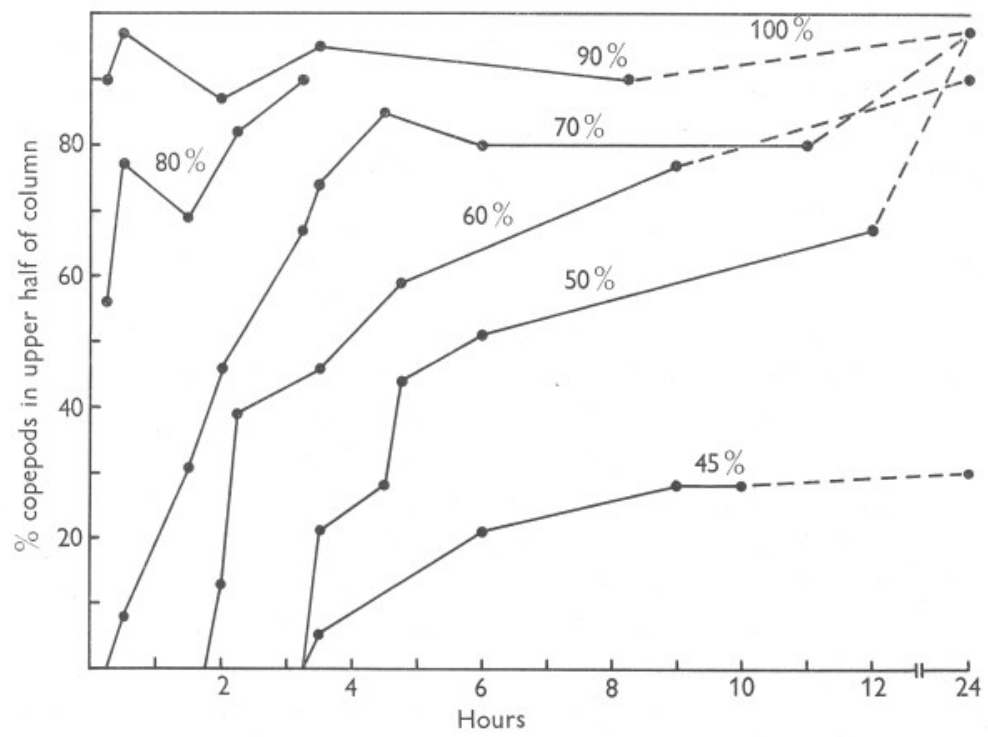

Fig. Io. Vertical distribution of Centropages hamatus in water columns of different salinities ( 50 females used in each column). $100 \%-45 \%=$ salinity ( $\%$ s.w.). 
the light. There was a lapse of about 15 min before copepods leaving the bottom of the experimental vessel reached the upper half of the water column. The increase in the number of animals entering the upper half was greater and more rapid for dilutions ranging from $90 \%$ to $60 \%$ S.W. than for the lower salinities.

It is clear that there were no consistent differences in behaviour between the various species over long periods of exposure to salinities ranging from $90 \%$ to $50 \%$ S.w. However, the increase in the number"of copepods migrating toward the surface during the early stages of exposure to $70 \%, 60 \%$ and $50 \%$ S.W. was more rapid for Acartia tonsa than for the other species and this trend was observed for the full experimental period in salinities below $50 \%$ s.w. Furthermore, $A$. bifilosa initially showed faster recovery than Centropages hamatus in both $60 \%$ and $50 \%$ s.w. Thus the species known to have the greatest salinity tolerances tended to show earlier recovery when placed in salinities lower than $80 \%$ s.w. In the lowest salinity used for each species, all copepods were confined to the bottom of the experimental vessel and none of the survivors made any vertical excursions. Acartia tonsa, the species with the greatest salinity tolerance, gave only transient signs of recovery in $10 \%$ s.w.; $A$. bifilosa showed no recovery in $30 \%$ s.w. as against $40 \%$ s.w. for Centropages hamatus the least tolerant species.

\section{DISCUSSION}

The behaviour of zooplankton in the presence of a single discontinuity layer clearly demonstrated that organisms attempting to swim toward the surface tended to collect on each side of the layer. Field evidence indicates that similar behaviour may occur in the natural environment (Nelson, I928; Hansen, I950; Carriker, 195I). Furthermore experimental tests conducted by Harder $(1952 b, 1957 b)$ showed that although polychaete larvae were indifferent to layering, copepods displayed a distinct preference for a salinity discontinuity layer and aggregated on both sides of it. All species taken from Southampton and Plymouth localities swam repeatedly toward the overhead light but always recoiled from the discontinuity layer when a critical dilution was present. Such avoidance of low salinities may be associated partly with sensory responses. In malacostracans, chemoreceptors may be situated on the antennulae, antennae, mouthparts and tips of appendages, as well as on the body surface. The perception of salinity variations may be associated with the osmotic stimulation of such sense organs (Krijgsman \& Krijgsman, 1954; Lagerspetz \& Matilla, I96I) and it is interesting to speculate whether planktonic crustaceans possess similar mechanisms which will allow the detection of chemical and physical changes occurring in the environment. In all experiments, a maximum number of individuals was recorded at the bottom of the water column when the critical salinity was present. Contact with water of low 

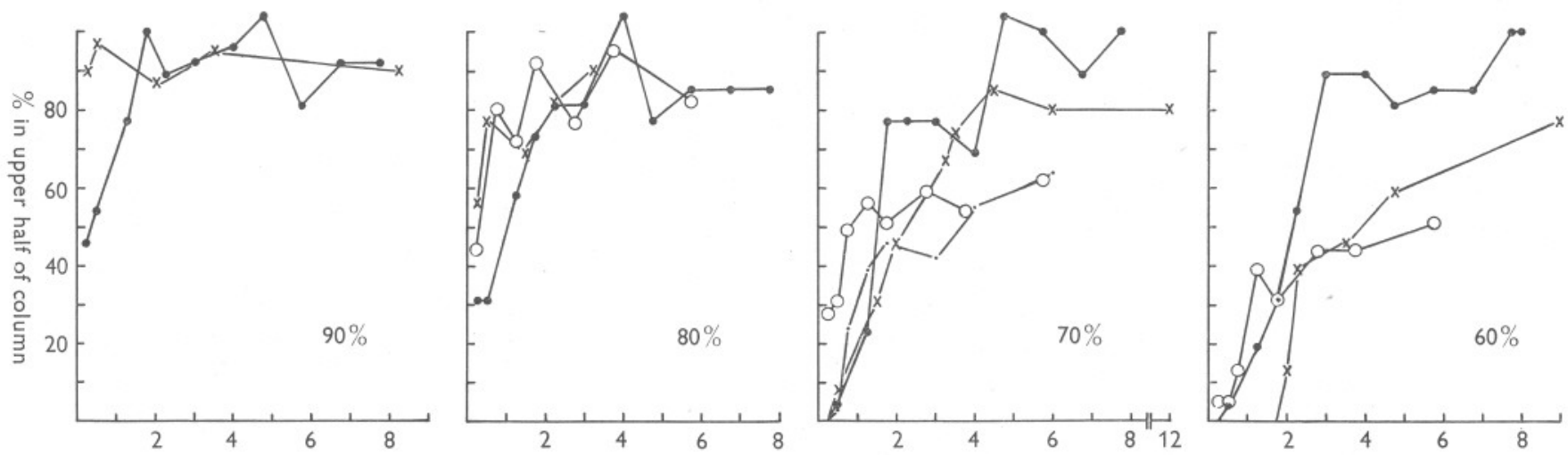

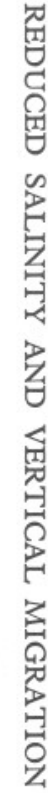
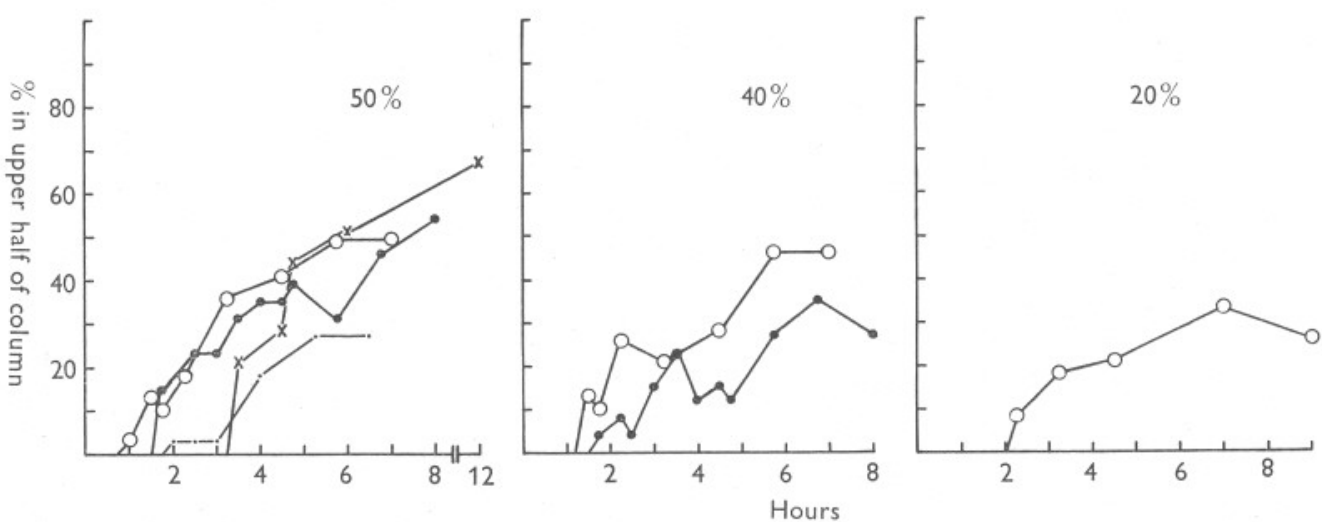

Fig. II. Vertical distribution of different copepod species in columns of diluted sea water. $\bigcirc-\mathrm{O}$, Acartia tonsa; .-, A. clausi; $\times--\times$, Centropages hamatus. A. bifilosa and C. hamatus showed no recovery in $30 \%$ s.w. and $40 \%$ s.w. respectively. 
salinity initially caused violent swimming movements which often carried animals down to the lower levels, but aggregation at the bottom may also have been associated with reversal of the phototropic sign whereby individuals became photonegative. Certainly the few experiments conducted on salinity effects indicate that diluted sea water can induce or augment negative phototropism (Loeb, 1893; Rose, 1925), and Russell (1927) has suggested that salinity might be one of the factors altering the sensitivity of plankton to light.

As only one experiment was conducted on each sex or stage of a particular species, only broad trends in behaviour can be considered in this paper. Behaviour was basically similar for all species, a modified pattern of vertical distribution being recorded even when the difference in salinity between the two zones of water was as small as $5 \% \mathrm{~s}$.w. In addition, it would appear that distribution was partly dependent on the salinity tolerances of individuals when low salinities were present. On the other hand, Harder (1954, I957b) found that copepods did not aggregate at a discontinuity layer resulting from a salinity difference of $14 \%$ provided that cane sugar was used to equalize the densities of the two salinities and he concluded that behaviour was related to density differences and not to salt concentration. Unfortunately glucose, gum arabic and thorotrast which can be used for altering the density of water were found to be unsuitable for the present investigation. While it is likely that density is an important factor determining behaviour, the results given in this paper indicate that salt concentration may also be a governing factor especially when large differences in salinity exist.

In the experiments using homogeneous columns of different salinities, it is probable that the violent movements occurring as soon as copepods were placed in dilutions at the lower end of the salinity range were associated mainly with a sudden osmotic flow of water into the body. Although swimming activity subsequently became depressed, many individuals became adapted to considerable hydration of the protoplasm and eventually resumed normal activity in all dilutions except those of lowest salinity. The effect of dilution appeared to be influenced to some extent by the salinity tolerances of the various species but it is probable that diluted sea water had a more direct effect on the flotation and swimming speeds of individuals. Preliminary attempts to estimate the sinking rates of anaesthetized Acartia have been unsuccessful since the slightest thermal currents either cause the small animals to float upward or increase the rate of sinking.

The results obtained from experiments using vertical series of discontinuity layers suggest that if salinity gradients are spread over some distance, there will be a progressive fall in the number of organisms present at any given depth as the upper levels are reached. Furthermore, the experiments demonstrating a depression of swimming activity in diluted sea water indicate that animals which do succeed in entering surface water of low salinity will be unable to maintain themselves there. Hence zooplankton will tend to aggre- 
gate in the bottom more saline water (cf. comments on field distribution made by Sewell, I913; Rees, I938; Rogers, I940; Carriker, I95I; Mankowski, I951; Pritchard, I953; Ketchum, I954; Barlow, 1955; Bousfield, I955; Hulburt, 1957) while species such as Temora longicornis and Porcellana longicornis which show strong swarming reactions (Farran, I910; Lebour, I943; Spooner, I933) may collect at intermediate depths.

This work was carried out whilst holding a Research Studentship awarded by the Department of Scientific and Industrial Research. I wish to thank Professor J. E. G. Raymont for departmental facilities and for many valuable suggestions and criticisms. I am grateful to the Director and Staff of the Marine Laboratory for facilities provided during the work at Plymouth.

\section{SUMMARY}

Effects of water of reduced salinity on the vertical migration of the zooplankton of Southampton Water were investigated in the laboratory using the adults of six copepod species (Acartia tonsa, A. bifilosa, A. discaudata, A. clausi, Centropages hamatus, Temora longicornis) and the larvae of one decapod species (Porcellana longicornis). Additional observations were made on Centropages typicus adults taken off Plymouth.

Salinity discontinuity layers had a marked effect on the vertical migration of zooplankton. A single discontinuity layer formed by placing less dense diluted sea water over full strength sea water acted as a barrier to animals attempting to swim toward the surface of an experimental water column and no individuals were able to enter the zone of reduced salinity when an extreme dilution was used. Comparison of the behaviour of various species and of different sexes or developmental stages of a particular species suggests that vertical distribution was partly dependent on the salinity tolerances of individuals. Upward migration was also restricted by a vertical series of discontinuity layers.

The swimming activity of copepods was depressed in homogeneous water columns of reduced salinity. Activity depended both on the degree of dilution and on the period of immersion. There were indications that behaviour varied according to the salinity tolerances of the different species.

\section{REFERENCES}

BARLOW, J. P., I955. Physical and biological processes determining the distribution of zooplankton in a tidal estuary. Biol. Bull., Woods Hole, Vol. I09, pp. 2 I I-25.

Bousfield, E. L., 1955. Ecological control of the occurrence of barnacles in the Miramichi estuary. Bull. nat. Mus. Canada, No. 137, 69 pp.

CARRIKER, M. R., I95I. Ecological observations on the distribution of oyster larvae in New Jersey estuaries. Ecol. Monogr., Vol. 21, pp. 19-38.

Farran, G. P., I9Io. Copepoda. Bull. Crois Pèr. Cons. Int. Explor. Mer, pp. 60-105.

Gross, F., I937. Notes on the culture of some marine plankton organisms. F. mar. biol. Ass. U.K., Vol. 21, pp. 753-68. 
Hansen, V. K., I95I. On the diurnal migration of zooplankton in relation to the discontinuity layer. F. Cons. int. Explor. Mer, Vol. I7, pp. 23I-4I.

HARDER, W., I952 a. Einige Geräte zur Herstellung von Wasserschichten verschiedener Dichte. Kurze Mitt. fischereibiol., Abt. Max-Planck-Instit., Nr. I, pp. 22-7.

$1952 b$. Über das Verhalten von Zooplankton in geschichtetem Wasser. Kurze Mitt. fischereibiol., Abt. Max-Planck-Instit., Nr. I, pp. 28-34.

—_ 1954. Weitere experimentelle Untersuchungen über dasVerhalten von Copepoden gegenüber Sprungschichten. Kurze Mitt. Instit. fischereibiol. Univ. Hamburg, Nr. 4, pp. I-I7.

- I957a. Das Verhalten von marinem Plankton gegenüber Sprungschichten. Zool. Anz., suppl-Bd. 20, Vom 21, p. 444.

- 1957b. Verhalten von Organismen gegenüber Sprungschichten. Année biol., T. 33, Fasc. 5-6, pp. 227-32.

HeNSCHEL, J., I959. Vertikale Wanderungen und unperiodische Schwankungen des Copepodenplanktons im Fehmarnbelt, Juni/Juli, 1936. Kieler Meeresforsch., Bd. 3, pp. 99-113.

HULBURT, E. M., 1957. The distribution of Neomysis americana in the estuary of the Delaware River. Limnol. Oceanogr., Vol. 2, pp. I-II.

Keтchum, B. H., I954. Relation between circulation and planktonic populations in estuaries. Ecology, Vol. 35, pp. I9I-200.

Krijgsman, B. J. \& KrijgSman, N. E., 1954. Osmorezeption in Fasus lalandii. Z. vergl. Physiol., Bd. 37, pp. 78-8I.

LAGERSPETZ, K. \& MATTILA, M., I96I. Salinity reactions of some fresh- and brackishwater crustaceans. Biol. Bull., Woods Hole, Vol. I20, pp. 44-53.

Lebour, M. V., I943. The larvae of the genus Porcellana (Crustacea Decapoda) and related forms. F. mar. biol. Ass. U.K., Vol. 25, pp. 72I-37.

LOEB, J., I893. Über künstliche Umwandlung positiv heliotropischer Tiere in negativ heliotropische und umgekehrt. Arch. ges. Physiol., Bd. 54, pp. 81-107.

LuKJANOVA, W. S., I938. The velocity of the movements of certain plankters and its dependence upon the external conditions. C.R. Acad. Sci. U.R.S.S., Vol. I9, pp. 5 I $7-19$.

Mankowski, W., I95I. Biological changes in the Baltic during the last 50 years. Rep. Sea Fisheries Inst. Gdynia, Nr. 6, pp. 95-I 18.

Nelson, T. C., 1928. On the formation of saliniclines in Barnegat Bay, New Jersey, with observations of the reactions of oyster larvae to salinity gradients. Anat. Rec., Vol. 4I, Abst. I69, pp. 84-5.

PRITCHARD, D., I953. Distribution of oyster larvae in relation to hydrographic conditions. Proc. Gulf and Carib. Fisheries Inst., 5th session, 1952, pp. 123-32.

ReEs, C. B., 1938. The plankton in the upper reaches of the Bristol Channel. F. mar. biol. Ass. U.K., Vol. 23, pp. 397-425.

ROGERS, H. M., I940. Occurrence and retention of plankton within the estuary. F. Fish. Res. Bd Can., Vol. 5, pp. 164-7I.

Rose, M., I925. Contributions à l'étude de la biologie du plankton; le problème des migrations verticales journalières. Arch. Zool. exp. gén., T. 64, pp. 387-542.

Russell, F. S., 1927. The vertical distribution of plankton in the sea. Biol. Rev., Vol. 2, pp. 213-62.

SEWELL, R. B. S., I913. Notes on the biological work of the R.I.M.S.S. 'Investigator' during survey seasons, I9IO-II and I9II-I2. F. Asiat. Soc. Bengal, Vol. 9, pp. 329-90.

SPOONER, G. M., I933. Observations on the reactions of marine plankton to light. F. mar. biol. Ass. U.K., Vol. 19, pp. 385-438. 